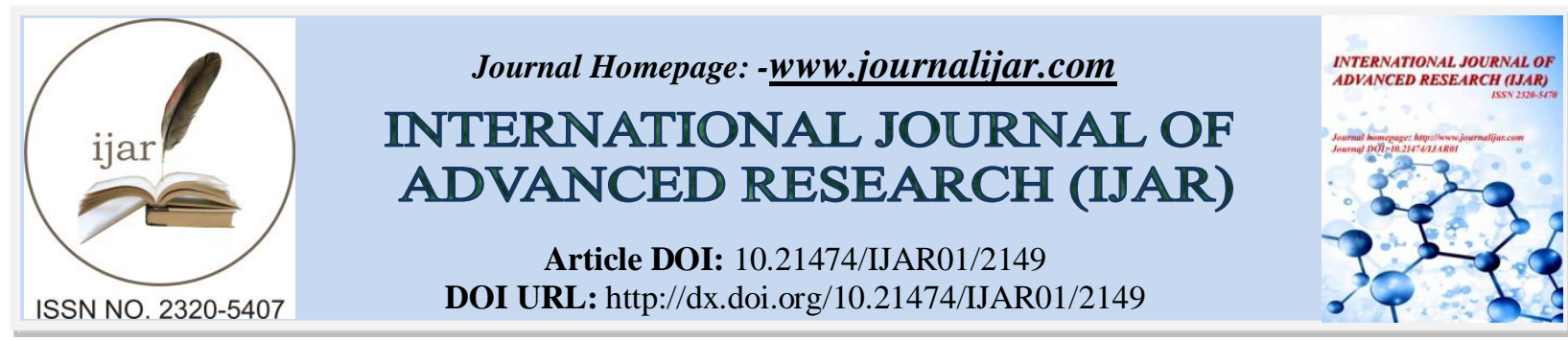

RESEARCH ARTICLE

\title{
DILEMMAS OF IT PROFESSIONALS WITH SPECIAL EMPHASIS ON MICROMANAGEMENT.
}

Sumi. K.V.

Research Scholar in Management,Kerala University Library Palayam, Trivandrum.

\section{Manuscript Info}

Manuscript History

Received: 25 September 2016

Final Accepted: 27 October 2016

Published: November 2016

Key words:-

Effects of micromanagement, Pros and Cons, True micromanagement

\begin{abstract}
Micromanagement is a management style whereby a manager closely observes or controls the work of subordinates or employees. A micromanager is typically one who is obsessed with over control and is overly concerned with all aspects of employee work. Micromanagement prevents innovation. Employees can't come up with new ideas and procedures on their own. Micro-managers are bad news for business and bad news for employees. Micromanagement breeds misery. Managers that do it wind up frustrating their employees and leaving even the most talented discouraged from doing their best. They dis-empower staff, stifle opportunity and innovation, and give rise to poor performance. Many well-intentioned, hard-working law enforcement supervisors and managers have been condemned as "micromanagers." Micromanagement destroys morale, increases turnover, and leads bosses to feel overworked and overstressed. Instead of focusing on bringing in new business or creating a winning business plan, a micromanager spends his time lording over a group of employees who feel stifled. So culturally taboo is the label within the workplace that many supervisors will go to any length to avoid the accusation and reputation. Although it is an apt title for some, there are misconceptions about what it means to be a true micromanager.
\end{abstract}

Copy Right, IJAR, 2016,. All rights reserved.

\section{Introduction:-}

We are living in a society that is making use of 'Information Highway' which is heading towards a real future "Global Village" of the Human history. The First Industrial Revolution used water and steam power to mechanize production. The Second used electric power to create mass production. The Third used electronics and information technology to automate production. Now a Fourth Industrial Revolution is building on the Third, the digital revolution that has been occurring since the middle of the last century. It is characterized by a fusion of technologies that is blurring the lines between the physical, digital, and biological spheres. By striking the potentialities of Steam, Electricity, Nuclear Energy and Information Technology, Humanity has witnessed three industrial revolutions and has reached the present state. With Artificial Intelligence at the heart of Information Technology, we are on the verge of stepping into the fourth industrial revolution which will empower Machines and Devices to possess the skill of 'thinking' and executing works just like humans do. The modern impact of Information Technology has broadened the base of computing and communication through satellite, fiber-Optic, mobile phone, fax machine, multi-media/hyper-media, e-commerce, m-commerce etc. Thus enhancing the implications of this shift from single, isolated technologies to a unified digital convergence and enhancing the computer users to experience a beautiful and fantastic scenario of computer utilization in various disciplines such as Robotics, 3D Printing, Genetics, 
Nanotechnology, Bio-Technology will have an important role to play in the fourth industrial revolution. Advent of Artificial Intelligence would substantially reduce the participation of humans in socio-productivity. The modern impact of information technology has expanded the base of computing and communication. Now information can be exchange through satellite, fiber-optic, mobile phone, and fax machine etc. The information technology has brought a revolution in our life style. The computer utilization is increased. Some important utilization is as follows:

Artificial Intelligence: It is a latest technology which is used in some electronic machines. These machines can think, decide themselves and communicate like human beings.

Web-Based Application: These are computer programs or software. These are used for connecting to the internet for exchanging information

E-commerce: It is a process of performing business transactions through computer network i.e. Internet.

M-commerce (Mobile commerce): It is a process of performing business transaction on the Internet through mobile phones

Computer Animation: The animation means cartoon or moving picture. Animation is a process of creating moving pictures and other special effects for televisions shows, commercials, movies and cartoons.

Multi-media: It refers to an application in which text, graphics, video and audio effects are incorporated Hyper-media: Hyper media is the process of creating links to multimedia files.

Distributed Computing: In distributed computing, a single task is performed on multiple computers.

With the advent of these technology,human resources who are behind the success of IT industry are greatly exploited due to non-existence of law to support employee welfare. In India, approximately 30 lakh employees are directly employed in IT sector. 10 lakh employees have attained indirect employment. $30 \%$ of those 30 lakh employees in IT sector are women that is 10 lakh women IT employees. $8 \%$ of internal production of India is contributed from IT sector and this sector contributes to $30 \%$ of total exports made by our country.

In our country, employees belonging to various traditional sectors such as government, private, small and large industries, skill and unskilled work have a way of resolving their grievances by associating themselves with Trade Unions and seeking government's intervention. There have been amendments made to Labor Act and Companies Act in order to facilitate startup of new companies in new industrial sectors. But at the same time, there has been no advises given to Courts or labor departments on which law would fundamentally safeguard the employees of these new sectors. So, the modern sector which has revolutionized to a greater extent the lifestyle of our society, - The Information Technology sector's employees find themselves in darkness whenever they are confronted with issues and have no legitimate place to go and seek justice.

Dilemmas of IT Professionals:-

\begin{tabular}{|c|l|}
\hline CAUSES OF FRUSTRATION & REASONS \\
\hline $1 . \quad$ Job Insecurity & $\begin{array}{l}\text { As there is no government mechanism existent which } \\
\text { can question the firing decision of companies, } \\
\text { employees of IT industry are in vulnerable position of } \\
\text { being dismissed from their companies anytime without } \\
\text { any justification. }\end{array}$ \\
\hline $2 . \quad$ Working time & $\begin{array}{l}\text { Length of their shifts have been extended due to work } \\
\text { pressure }\end{array}$ \\
\hline 3. Forced resignation $\quad$ Non Transparent Appraisal System & $\begin{array}{l}\text { The ultimate effect is forced resignation, whenever an } \\
\text { employee raise their voice against workplace bias. }\end{array}$ \\
\hline $5 . \quad$ Gender discrimination at workplace & $\begin{array}{l}\text { Decision of fitting the employees to categories like } \\
\text { excellent,average,poor solely rests with the manager and } \\
\text { hence it is prone to partiality/bias } \\
\text { Marriage and Maternity has become to be a hindrance }\end{array}$ \\
\hline
\end{tabular}




\begin{tabular}{|c|c|}
\hline & $\begin{array}{l}\text { for job continuation of women employees in IT sector. } \\
\text { Appraisal rating and the benefits that sprouts from it } \\
\text { namely salary hike and promotion have a significant } \\
\text { difference between before \& after Marriage and likewise } \\
\text { before \& after Maternity }\end{array}$ \\
\hline 6. Disappearance of companies & $\begin{array}{l}\text { There are many IT companies in our country that have } \\
\text { been started on relatively small investments. Employees } \\
\text { working for these small IT companies have no guarantee } \\
\text { that their monthly salaries and PF amounts will be } \\
\text { reaching them without any delay. These companies have } \\
\text { the liberty to shut down their operations and disappear } \\
\text { from the country anytime and there is no government } \\
\text { machinery existent that can question this. }\end{array}$ \\
\hline 7. Defying the right of fixed working hours & $\begin{array}{l}\text { In IT sector, there are no clearly defined working hours } \\
\text { and if the day needs working for many hours together, } \\
\text { no employee can raise voice against it. If the project } \\
\text { needs employee working on weekends, it should be done } \\
\text { at whatever cost. If the completion of task actually needs } \\
\text { effort from two employees but if only one is assigned, } \\
\text { the employee cannot question such decision. }\end{array}$ \\
\hline 8. Work life imbalance & $\begin{array}{l}\text { Employees of IT industry find it difficult to manage } \\
\text { work with family life as the work life is highly } \\
\text { challenging.as }\end{array}$ \\
\hline 9. Right to unite as Trade Unions & $\begin{array}{l}\text { Disputes happening at workplaces are being arbitrated in } \\
\text { favour of the management by the company's Human } \\
\text { Resource Manager itself. The right of unionizing which } \\
\text { is exercised by the employees of traditional sectors are } \\
\text { not being made available for the employees of this } \\
\text { modern IT sector. }\end{array}$ \\
\hline 10. Health issues & $\begin{array}{l}\text { The common health problem are stress, acid peptic } \\
\text { disease, alcoholism, asthma, diabetes, fatigue, tension } \\
\text { headache, hypertension, insomnia, irritable bowel } \\
\text { syndrome, psychoneurosis, sexual dysfunction and skin } \\
\text { diseases such as psoriasis, lichen planus, urticaria, } \\
\text { pruritus, neurodermatitis,eye strain,heart problem }\end{array}$ \\
\hline 11. Micro management & $\begin{array}{l}\text { Micromanagers hinders the productivity and innovative } \\
\text { ability of the employees }\end{array}$ \\
\hline
\end{tabular}

\section{Impact of micromanagement:-}

Micromanagement generally has a negative connotation. It is the management's attempt at digging its fingers deep into the pie of those actually doing the work. It's a way for management to ensure that tasks are performed in a very precise manner. Management will make the employees to work hard with tight deadlines and excessive supervision. A micromanager is typically one who is obsessed with control and is overly concerned with all aspects of employee work. Micromanagers tend to dictate every detail of the work for which their subordinates are responsible, and they truly believe that their way is not only the best but also the only way to accomplish a goal. Rather than help, true micromanagers impede work progress and risk stifling the growth of subordinate officers as well as the police agency as a whole. Studies have shown, however, that micromanagement is effective over the short term. Simply by virtue of their position, supervisors are best suited to select an immediate course of action, provide direction, and oversee results ensuring that vital tasks are completed on time and without error. But if such stringent management is left unabated for a longer period, it will have several destructive effects. The micromanager often assign work and then micromanage the work to enable the oppressive manager to take credit for any positive results, and also to blame the employee for negative results. In this scenario the micromanager actually delegates the accountability for failure to the worker without giving them the ability to take initiative that might have made the project a success. Micromanagement in an organisation can be understood by the symptoms revealed belowSymptoms of micromanagement in organisationMicromanagers cannot let an employee function independently. They need to be in 
constant control of the process, observing in minute detail and assessing, commenting and giving suggestions, even when not required. They find it hard to delegate responsibility and end up being over involved in tasks that they could easily have left to their subordinates. The following symptoms clearly exhibits the existence of micromanagement in the organisation.

1. Resist delegating work. A micromanager always resist sharing of work with subordinates. He always performs the job by himself without delegating the work.

2. Immerse themselves in the work assigned to others. Micromanagers indulge in work which are assigned to other members of the team. They try to perform the tasks which are assigned to themselves and others and take the credit of the success of the work.

3. Look at the detail instead of the big picture .Micromanagers pin point each and every mistakes even though there is ultimate success. Micromanagers are eager to find faults in others and blame them for their negatives.

4. Discourage others from making decisions.Micromanagers always take decisions on their own without considering others opinion. Even if good ideas are raised by the colleagues, micromanagers discourage it by finding any minor fault.

The above mentioned are some of the major symptoms of existence of micromanagement in organisations. They always get involved in the work of others without consulting them andmonitor what's least important and expect regular reports on miscellany. They push aside the experience and knowledge of colleague, loose loyalty and commitment, focus on the wrong priorities. Micromanagers always have a de-motivated team. Subordinates appear frustrated, depressed, and/or unmotivated. Micromanagers cannot mind their own business. They have to be involved with overseeing other people's projects too. Most of the time, they get stuck in tiny unnecessary details and refuse to look at the whole picture. Very often, if and when they find a tiny mistake or problem, they will take back the work they had delegated and try to finish it themselves. Micromanagers do not take well to initiatives shown by their subordinates nor do they appreciate independent decision making without their consent. They demand reports at every stage of progress and have a need to be in the know, and no decision can be taken without their blessing. Most of the time, the comments and inputs provided by the micromanager are counterproductive and trivial.

\section{Effects of Micromanagement:-}

Micromanagers are usually irritated when a subordinate makes decisions without consulting them, even if the decisions are within the subordinate's level of authority. Micromanagement also frequently involves requests for unnecessary and overly detailed reports ("reportomania"). A micromanager tends to require constant and detailed performance feedback and to focus excessively on procedural trivia (often in detail greater than they can actually process) rather than on overall performance, quality and results. There are various negative effects for micro management, which is described below

\section{Micromanagement prevents innovation.}

Employees can't come up with new ideas and procedures on their own; they have to constantly check with the micromanager who is often unavailable. . Employees with skills and knowledge will leave such situations and the organization is left with workers who are content to wait to follow instructions.

\section{Micromanagement slows workflow.}

As all approvals have to go through the manager who will not give up control. It is not efficient for normal work to have to wait for approval from a micromanager. Delegation is an essential element in any organization and it is an essential skill for any manager.

\section{Micromanagement prevents an organization from using the talents and skills of the staff.}

Employees are hired because they have the knowledge and ability to do a job. If they are constantly being hovered over by an oppressive manager, then they cannot do the jobs that they were hired to do.

\section{Micromanagement retards communication within a school or office and with the community.}

When someone asks a question, workers will often reply, "I'll have to check with my manager." Employees should be able to respond to coworkers and with the community without being held hostage. The damage that is caused by inaccurate communications is not nearly as great as the damage that is caused by communicating in a timely manner.

\section{Micromanagement discourages teamwork.}

Managers should encourage everyone in the organization to constantly be innovating, communicating and improving and this cannot be done if the manager cannot delegate and respect the work of his or her employees. As 
a result team work cannot be properly accounted.

How to Manage a Micromanager:-

There are some practical steps to control the micromanagers. First of all understand the reason why the manager is behaving in such manner. It may be from lack of confidence, workplace instability and pressure to produce-both individually and as a team. Deep-seated psychological issues and problems at home can also influence the way people behave at work.

\section{Look for patterns.}

Micro managers are often predictable by understanding the situations or times of the day or week, when they get especially agitated. Knowing such pressure points their behaviour can be controlled.

2. Anticipate needs.

Once you know what triggers them, you can stay ahead of those stressors and ease the tensions early on. Flag potential problems before they escalate and offer solutions.

3. Show empathy.

Remember, the micromanager is under pressure to produce. Show that you understand his or her plight and are willing to share the load. This could be as simple as offering to help.

\section{Be super reliable.}

It's much easier to manage an office where everyone turns up on time and meets work deadlines. This goes back to the fact that a micromanager hates feeling out of control. If some members of the team don't deliver, the micromanager gets aggravated and makes unfair demands on everyone else. Discuss as a team what you can do to coordinate things in such a way that there's no need for the micromanager to fret about how everything is running.

\section{Be a role model.}

Treat the micromanager the way you would like to be treated. Give the micromanager space. Don't smother or micromanage back. In working with other people, show how your management style is different -and gets equally good results.

\section{True Micromanagement:-}

Not all supervisors who micromanage do so intentionally or even knowingly. Most are acting on what they perceive to be the best interest of their agencies and are unaware that their workers are discontent. In this regard, there are circumstances and other factors that may unwittingly cause supervisors to engage in micromanagement. Pressure from the agency's administration for better performance can often lead to supervisors taking excessive control. These supervisors believe that a failure to increase productivity, quality, or quantity will reflect poorly on their ability and will therefore have a negative impact. Too often in organizations, supervisors are rewarded for results rather than the process. Newly promoted supervisors might have problems adjusting to their new responsibilities. The attention to detail, control, and autonomy that was important as an officer before promotion follows into the new position. The new supervisor fails to see the "big picture" of the responsibilities attendant with promotion. As such, there can be problems with delegation and teamwork. Many will return to what is comfortable and familiar, performing tasks themselves to ensure that the work is done properly. There may be a lack of trust in subordinate officers. This can result from previous performance issues or simply from unfamiliarity with the work histories and ethics of officers under a supervisor's command. It may also stem from the supervisor's own insecurity.

Similar to a lack of trust, some supervisors believe in their self-perceived "superior" ability compared with that of their subordinates. In this situation, there is a failure to empower subordinate officers, thereby stifling creativity, job knowledge, and professional development. Finally, some well-intentioned supervisors erroneously mistake micromanagement for mentoring. Rather than utilizing mentorship strategies (such as setting goals, building a vision, offering counsel and support, and modelling appropriate behaviour) these supervisors strictly direct, control, and assume subordinates' work under the flawed belief that officers will benefit from a more hands-on, direct approach.

\section{Pros \& Cons Of Micromanagement:-}

Micromanagement may be good under certain circumstances, but still people don't enjoy it.

It has the potential of demoralizing people, creating lack of trust and a dysfunctional work environment. No concept is all good or all bad, its success or failure depends upon the way in which it has been implemented. Though most people think that micromanagement is counterproductive, it cannot be ignored without looking at the advantages and disadvantages of the practice before passing a verdict. 


\section{When It Is Good for Business:-}

Micromanagement, when done properly, can be highly productive and help a company, especially for a new venture looking to streamline its productivity and manage resources in a more efficient manner.

Micromanagement is good for a business in the following circumstances:

1. Hiring new people: In order to get the best candidate for the job, it is essential to have a very methodical process in place before calling a person for an interview. This is essential, so that time and effort are not wasted on the wrong candidate. So, scrutinizing each candidate is good.

2. Starting new processes or ventures: When beginning a new venture or a process, it is essential to micromanage it, in order to discover any loopholes, problem areas or bottlenecks in the process and eliminate them.

3. Facing financial or legal problems: When a project or a company is in trouble, then micromanagement is good. It becomes essential to look at all the details, however minute, to find the cause of the problem and plug the leak so that the problem can be solved. This is the time when all employees and their work come under scrutiny and micromanagement.

4. Employees have a track record of being problematic: If there is an employee who is known to be problematic, it is important to keep a close eye on his/her performance and actions. This may improve performance, and if it doesn't, then perhaps it is time for you to let the employee go.

5. Engaging in high-risk activities: People working in hazardous industries or involved in high-risk activities need to be micromanaged. This is done for their own safety. Any slip ups in such circumstances could mean life and death, and hence close attention needs to be paid.

6. Changing strategy: If a business is changing strategy or making big changes within the organization, micromanagement is good. It helps everyone involved to understand the process and how the changes will impact their role and duties.

7. Changing top management: When there is a change in top management, business owners need to micromanage so as to familiarize the new executive to the work environment. Even the most experienced person needs guidance to slip into their new role.

\section{When It Is Bad for Business:-}

Excess managing is detrimental to the growth and well-being of an organization. Micromanagement has the potential of too much scrutiny, and this can be counterproductive. It can become a problem when:

1. It hampers growth and learning: Too much control is not good, for it kills the desire in employees to learn and grow. When an employee knows that he/she is being constantly watched and will be interrupted at every stage, they lose the desire for self-improvement and enhancement.

2. It prevents evaluation of skills: It is difficult to assess the skills of employees who are being micromanaged, as it is unclear what they have done themselves and what they have been directed to do by the micromanager. Most micromanagers do not let their subordinates take ownership of their work.

3. It affects employees' performance: Over scrutinizing is demoralizing and creates self-doubts in the employees, which eventually ends in affecting their performance. The employees know that they will not be allowed to work independently or given credit and hence do not put in any extra efforts or add anything more to the task than is asked.

4. It kills motivation and innovation: Constant criticism and scrutiny also kill initiative. When the micromanager takes over the task, and there is no scope for inputs from anyone else, it kills innovation and creativity and demotivates the team.

5. The micromanager loses control: A micromanager will eventually lose control over the team. Since they use only control to manage their subordinates, soon it becomes ineffective as the employees get used to the bullying, or they leave and seek employment elsewhere.

6. There is a loss of trust and mutual appreciation: Micromanagement breeds distrust and dislike. Such an environment, within an organization, is not conducive to growth and productivity. When the atmosphere at work becomes too oppressive, the productivity drops and good employees leave.

7. It creates dependency: Since a micromanager does not allow initiative and inputs from other people in the team, the employees learn to leave all decision-making to the manager and become totally dependent on him/her.

8. It results in a high attrition rate: One side effect of micromanagement is a high attrition rate, where good employees leave the organization and join rivals or parallel ones. Most creative and hardworking people do not like being under the microscope all the time and prefer to move on.

9. It results in increased workload and burnout: When someone is micromanaging they are essentially taking on work that has been assigned to someone else. So micromanagers end up doing double the work, which they could have easily avoided if they had not micromanaged. This causes the overburdening of one individual, in this case, the micromanager, and can lead to burnout. It also hampers the production process by causing bottlenecks and delays. 


\section{Conclusion:-}

Micromanagement is not all bad; it does have its benefits in certain circumstances and conditions. If it is done in a proper manner, it can be beneficial for an organization. Managers need to be aware of their employees' performance and attitude, but this should be done in a manner that is not hyper critical. They need to be able to deal with people in a respectful and polite manner, and ensure that the inputs that they are giving add to the process and do not unnecessarily bog it down with details. Employees, on the other hand, need to be proactive with their responsibilities, and if they feel they are being micromanaged, do something about it. Whether it is the micromanager or the micromanaged, both need to take stock of the situation. If the micromanagement is becoming restrictive and oppressive, try to remedy it, as sooner or later, it will start to affect the overall productivity of the organization.

\section{References:-}

1. Florence Stone, "Micromanagement: How to Think More Strategically and Less Operationally," Performance and Profits (American Management Association) 1, no. 4 (April 2006),

2. Christina Bielaszka-DuVernay, "Essentials: Micromanage at Your Peril," Harvard Management Update 12, no. 2 (February 2007)

3. Susan K. O'Brien, "Managing Your Micromanager," cited in Richard L. Porterfield, "The Perils of Micromanagement," Contract Management 43, no. 2 (February 2003)

4. Craig Chappelow, "Is George Guilty of Micromanagement?" in Bronwyn Fryer, "The Micromanager," Harvard Business Review 82, no. 9 (September 2004)

5. 5Steve Lemmex, "What Is Micromanagement? And What You Can Do to Avoid It," Global Knowledge Training, 2007,

6. Joel Brockner, "Why It's So Hard to Be Fair," Harvard Business Review 84, no. 3 (March 2006): 122129,articleID=R0603H\&ml_action=get-article\&print=true (accessed June 11, 2008).

7. AdamHanft, “Grist: Micromanagers, Unite!” Inc.com, December 2004, 128,

8. Wally Adamchik, "Supervising Employees: When Your Supervisors Micromanage," The Sideroad,

9. Josephine Rossi, “Micromanagement: Necessary Evil, Evil Incarnate, or Something In-Between?” T+D, July 2005, 18,Lemmex, "What Is Micromanagement?"

10. MikeToten, "What If You Are the Micromanager?" WorkplaceInfo, August 16, 2005,Joan Lloyd, "Are You a Micromanager?" Joan Lloyd at Work, August 22, 2007,Laura Whitworth, Henry Kimsey-House, and Phil Sandahl, Co-Active Coaching: New Skills for Coaching People toward Success in Work and Life (Palo Alto, California: Davies-Black Publishing, 1998).

11. For additional information, see Tracey G. Gove, "Praise and Recognition: The Importance of Social Support in Law Enforcement," FBI Law Enforcement Bulletin 74, no. 10 (October 2005): 14-19,

12. Jeff Davis, "Tips for Coping with a Micromanager," TechRepublic, July 9, 2002,

13. Harry E. Chambers, "How to Succeed with a 'My Way' Boss," Career-Intelligence.com, 2004,

14. Beverly West, "Manage Your Micromanager," Monster Career Advice, 2007,

15. http://career-advice.monster.com/conflict-management/Manage-Your-Micromanager/home.aspx

16. http://www.amanet.org/performance-profits/editorial.cfm?Ed=251

17. http://www.ncmahq.org/files/Articles/5531D_micromanage.pdf

18. http://dorawood.com/viewFileNavBean.pdf

19. http://images.globalknowledge.com/wwwimages/whitepaperpdf/WP_Micromanage_Lemmex.pdf

20. http://www.inc.com/magazine/20041201/ahanft.html

21. http://www.sideroad.com/Leadership/ supervising-employees.htm

22. http://findarticles.com/p/articles/mi_qa5366/is_200507/ai_n21375269

23. http://www.workplaceinfo.com.au/nocookie/alert/2005/050816530.htm

24. http://www.joanlloyd.com/articles/open.asp?art=/articles/1227.htm

25. http://www.fbi.gov/publications/leb/2005/oct05leb.pdf

26. http://articles.techrepublic.com.com/5100-1035_11-1043727.html

27. http://www.career-intelligence.com/management/Micromanager.asp 